International Journal of Zoological Investigations

Contents available at Journals Home Page: www.ijzi.net

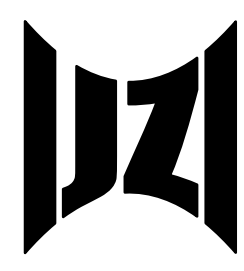

ISSN: 2454-3055

\title{
In-vitro Bioefficacy Screening of Some Insecticides Against Fall Armyworm (Spodoptera frugiperda J. E. Smith) (Lepidoptera : Noctuidae)
}

\author{
Bansode Sagar B. ${ }^{1 *}$, Kumar Mohan D. ${ }^{2}$, Santha Kumar M.V. ${ }^{1}$ \\ 1Department of Zoology, Shivaji University, Kolhapur, Maharashtra, India \\ 2Department of Agrochemicals and Pest Management, Shivaji University, Kolhapur, Maharashtra, India \\ ${ }^{*}$ Corresponding Author
}

Received: $14^{\text {th }}$ June, 2020

Accepted: $16^{\text {th }}$ July, 2020

Published online: $20^{\text {th }}$ July, 2020

https://doi.org/10.33745/ijzi.2020.v06i02.009

\begin{abstract}
Fall armyworm (FAW), Spodoptera frugiperda (L. E. Smith) is one of the most destructive pests in tropical and subtropical regions of world and is introduced to Indian subcontinent, causing substantial damage on variety of crops. Considering the necessity of developing pest management strategies we made an attempt to screen the bioefficacy of three insecticides-- emamectin benzoate, imidacloprid and chlorpyriphos under laboratory conditions. Our investigation revealed the toxic effects of selected insecticides against third instar larvae of FAW. Emamectin benzoate being most effective against the pest.
\end{abstract}

Keywords: Fall armyworm, Bio-efficacy, Emamectin benzoate, Imidacloprid, Chlorpyriphos

Citation: Bansode Sagar B., Kumar Mohan D., Santha Kumar M.V.: In-vitro bioefficacy screening of some insecticides against fall armyworm (Spodoptera frugiperda J. E. Smith) (Lepidoptera : Noctuidae). Intern. J. Zool. Invest. 6 (2): 306-310, 2020. https://doi.org/10.33745/ijzi.2020.v06i02.009

\section{Introduction}

Maize is third widely grown crop in India after rice and wheat. Maize often found infested by many insects pests like stem borer, stem fly, pink stem borers and aphids. Among them, recently introduced invasive pest fall armyworm (FAW), (Spodoptera frugiperda (L. E. Smith); Lepidoptera: Noctuidae) is found most destructive, causing substantial damage to all stages of the host plant (Koffi et al., 2020). FAW is native of tropical and subtropical regions of America and also introduced in Africa (Day et al., 2017) causing severe food insecurity. In India it was reported from Karnataka (Ali et al., 1990), soon spread to all southern states of India including Maharashtra (Andrews, 1990; Belay 
et al., 2012). FAW has been reported highly polyphagous and attained ability to infest wide variety of field crops and vegetable crops (Daves et al., 2009).

The initial larval instars of FAW cause damage by feeding (scratching) on the foliage, whereas the later instars feed on the growing point of plant which causes dead heart symptoms. When FAW infests the older plants they feed on maize cob and kernels which leads to drastic reduction in yield and quality of the production (Capinera, 2017, Ganiger et al., 2018). Chemical control of insect pests is one of the commonest methods to combat the infestation of pests. Insecticides are popular among the farmers because of their quick action and recovery of infected plants. Cotton is one of the hosts of FAW, and its control on cotton is difficult with insecticides. Larvae are usually distributed low in the plant canopy (Malo et al., 2004), and inadequate insecticide deposition in the lower portions of the cotton plant seems to be one limiting factor in controlling this pest (Mink and Luttrell, 1989). Insecticides that are used to control the tobacco budworm, Heliothis virescens (F.), and the cotton bollworm, Helicoverpa zea (Boddie), often are ineffective against fall armyworms (Prasanna et al., 2018).

Emamectin benzoate is one to the most popular and very potent insecticides used against wide variety of lepidopteran insects. IRAC classified emamectin benzoate in group 6 glutamate gated chloride channel allosteric modulators. Imidaclprid is a special class of insecticide belongs to chemical group neonicotinoids which acts on the nicotinic acetylcholine receptors in central nervous system of insects. Chlorpyriphos is an organophosphorus insecticide which owes its insecticidal activity by blocking acetylcholine enzyme at central nervous system. In this study we made an attempt to screen three different insecticides (emamectin benzoate, imidacloprid and chlorpyriphos) for their ability to cause lethal effects on third instar larvae of FAW under laboratory conditions.

\section{Materials and Methods}

Insect Rearing:

Rearing was initiated using the larvae collected from maize fields of College of Agriculture, Kolhapur. The collected larvae were reared in the laboratory at $22 \pm 3 \mathrm{C}$ and $70 \pm 5 \% \mathrm{RH}$. The larvae were fed with fresh and healthy maize leaves in the rearing chamber. Pre-pupal state were identified and displaced to plastic container containing three-fourth of solarized soil. Subsequently, plastic containers were covered with black cloth for pupation. Emerged adults were provided with $10 \%$ honey solution soaked cotton. Fresh maize leaves were provided every day for egg deposition. The laid eggs were collected on daily basis and kept for incubation at $38 \mathrm{C}$. Third instar larvae of this generation were used for bioassay.

Preparation of insecticide solutions:

Insecticides (Imidacloprid 18.7\% SL, Emamectin benzoate 5\% WDG and Chlorpyriphos 20\% EC) were purchased from local market. Different concentrations of each insecticide (emamectin benzoate- 0.05, 0.1, $0.5,0.8$ and $1 \%$; imidacloprid-- $0.5,1.0,1.5$, $2.0,2.5,3.0,3.5,4.0,4.5$ and $5 \%$; and chlorpyriphos -- $0.5,1.0,1.5,2.0,2.5,3.0,3.5$, $4.0,4.5$ and $5 \%$ ) were prepared using distilled water.

\section{Bioassay:}

Third instar larvae were used to perform bioassay. $10 \mu \mathrm{l}$ of each concentration of each 
insecticide were separately applied topically using micropipette on each larva. Further, the larvae were transferred to a plastic container provided with fresh leaves of maize. Only one larva was allowed in each container to avoid cannibalism which is very common in this species. Mortality was observed at 24, 48 and $72 \mathrm{~h}$ and results were recorded. Ten replications were carried out for each test solution. The results are illustrated in Tables 1-3.

\section{Results}

Table 1 displays the efficacy of imidacloprid to cause lethal effect. The $3^{\text {rd }}$ instar larvae of FAW are quite resistant to lower concentration of Imidacloprid. Imidacloprid at 0.5 and $1.0 \%$ cause no lethal effect till $72 \mathrm{~h}$ after treatment, but $1.5 \%$ caused $50 \%$ mortality at $72 \mathrm{~h}$. Imidacloprid at 4.5 and $5 \%$ was very toxic against larvae which caused 70 and $73 \%$ mortality within $24 \mathrm{~h}$, and 90 and $100 \%$ mortality at $72 \mathrm{~h}$ after application, respectively.

Table 1: Bio-efficacy results of imidacloprid against third instar larvae of FAW.

\begin{tabular}{|c|c|c|c|}
\hline \multirow{2}{*}{$\begin{array}{c}\text { Concentration } \\
\text { (\%) }\end{array}$} & \multicolumn{3}{|c|}{ Mortality (\%) } \\
\cline { 2 - 4 } & $\begin{array}{c}\mathbf{2 4} \\
\text { Hours }\end{array}$ & $\begin{array}{c}\mathbf{4 8} \\
\text { Hours }\end{array}$ & $\begin{array}{c}\mathbf{7 2} \\
\text { Hours }\end{array}$ \\
\hline 0.5 & 0 & 0 & 0 \\
1.0 & 0 & 0 & 0 \\
1.5 & 0 & $10 \pm 4$ & $50 \pm 4$ \\
2.0 & $15 \pm 5$ & $18 \pm 5$ & $33 \pm 5$ \\
2.5 & $27 \pm 3$ & $30 \pm 3$ & $35 \pm 3$ \\
3.0 & $53 \pm 3$ & $65 \pm 3$ & $73 \pm 3$ \\
3.5 & $55 \pm 5$ & $57 \pm 4$ & $57 \pm 5$ \\
4.0 & $55 \pm 4$ & $85 \pm 5$ & $90 \pm 5$ \\
4.5 & $70 \pm 5$ & $85 \pm 4$ & $90 \pm 5$ \\
5.0 & $73 \pm 5$ & $92 \pm 5$ & $100 \pm 0$ \\
\hline
\end{tabular}

Values are mean \pm SE of 10 replicates

Table 2 shows the effect of emamectin benzoate against $3^{\text {rd }}$ instar larvae. Among the insecticides tested, emamectin benzoate found significantly toxic at lower concentrations. As explained in Table 2, 0.8 and $1 \%$ concentration of emamectin benzoate caused $100 \%$ mortality within $24 \mathrm{~h}$. Even 0.1 and $0.5 \%$ emamectin benzoate caused more than $75 \%$ mortality after $72 \mathrm{~h}$ of treatment.

Table 2: Bio-efficacy results of emamectin benzoate against third instar larvae of FAW.

\begin{tabular}{|c|c|c|c|}
\hline $\begin{array}{c}\text { Concentration } \\
\text { (\%) }\end{array}$ & \multicolumn{3}{|c|}{ Mortality (\%) } \\
\cline { 2 - 4 } & $\begin{array}{c}\mathbf{2 4} \\
\text { Hours }\end{array}$ & $\begin{array}{c}\mathbf{4 8} \\
\text { Hours }\end{array}$ & $\begin{array}{c}\mathbf{7 2} \\
\text { Hours }\end{array}$ \\
\hline 0.05 & $30 \pm 2$ & $70 \pm 0$ & $70 \pm 0$ \\
0.10 & $40 \pm 5$ & $55 \pm 4$ & $78 \pm 5$ \\
0.50 & $80 \pm 4$ & $85 \pm 6$ & $90 \pm 2$ \\
0.80 & $100 \pm 0$ & $100 \pm 0$ & $100 \pm 0$ \\
1.00 & $100 \pm 0$ & $100 \pm 0$ & $100 \pm 0$ \\
\hline
\end{tabular}

Values are mean \pm SE of 10 replicates

Table 3 illustrates the toxicity of chlorpyriphos on FAW. Chlorpyriphos at 0.5, 1 and 1.5 concentrations caused no mortality after $24 \mathrm{~h}$ of application. Higher concentrations i.e. $4,4.5$ and $5 \%$ of chlorpyriphos caused 70,73 and $95 \%$ mortality after $24 \mathrm{~h}$ of application, respectively. It is apparent that higher

Table 3: Bio-efficacy results of chlorpyriphos against third instar larvae of FAW.

\begin{tabular}{|c|c|c|c|}
\hline $\begin{array}{c}\text { Concentration } \\
\text { (\%) }\end{array}$ & \multicolumn{3}{|c|}{ Mortality (\%) } \\
\cline { 2 - 4 } & $\begin{array}{c}\mathbf{2 4} \\
\text { Hours }\end{array}$ & $\begin{array}{c}\mathbf{4 8} \\
\text { Hours }\end{array}$ & $\begin{array}{c}\mathbf{7 2} \\
\text { Hours }\end{array}$ \\
\hline 0.5 & 0 & 0 & 0 \\
1.0 & 0 & 0 & 0 \\
1.5 & 0 & $5 \pm 3$ & $45 \pm 5$ \\
2.0 & $5 \pm \mathbf{1}$ & $40 \pm 5$ & $45 \pm 6$ \\
2.5 & $30 \pm 4$ & $40 \pm 5$ & $45 \pm 4$ \\
3.0 & $50 \pm 5$ & $55 \pm 4$ & $78 \pm 5$ \\
3.5 & $57 \pm 6$ & $77 \pm 5$ & $75 \pm 4$ \\
4.0 & $70 \pm 4$ & $90 \pm 5$ & $100 \pm 0$ \\
4.5 & $73 \pm 5$ & $95 \pm 6$ & $100 \pm 0$ \\
5.0 & $95 \pm 4$ & $95 \pm 5$ & $100 \pm 0$ \\
\hline
\end{tabular}

Values are mean \pm SE of 10 replicates 
concentration of chlorpyriphos are needed to cause lethal effect on FAW, whereas lower concentrations caused no significant mortality.

\section{Discussion}

In this study, all of the synthetic insecticides tested were toxic to FAW larvae. In the laboratory bioassays, moderate to high larval mortality was achieved with imidacloprid, emamectin benzoate and chlorpyriphos. It was noted that in the laboratory trials, the per cent larval mortality increased over time after insecticides application, which indicate residual toxicity of the synthetic insecticides to FAW. As is common with other insect pest species, synthetic insecticides are important management options in FAW control in the America (Andrews, 1990). In Mexico, chemical control of FAW in maize is achieved by the application of methyl parathion, methamidophos, and phoxim, among other synthetic insecticides (Ganiger et al., 2018). In Florida, FAW is one of the most important sweetcorn pests, and synthetic insecticides are applied against FAW to protect both the vegetative stages and reproductive stage of corn (Capinera, 2017). Several insecticide applications are required to kill larvae feeding deep in the whorl of plants. Some of the synthetic insecticides reported by those authors corroborate the findings of the present study. Kondidie (2011) reported $>60 \%$ FAW mortality $16 \mathrm{~h}$ after application of Radiant, Orthene, and Larvin. In another study, Intrepid 2F, Lannate 2.4LV, Sevin XLR Plus $4 \mathrm{~F}$, and Tracer $4 \mathrm{SC}$ effectively reduced FAW larvae under fulfilled conditions (Daves et al., 2009). Hence, sprayings should be spaced evenly during the growing period instead of concentrated at the silking period (Sisay et al., 2019).
Although synthetic insecticides are effective to control FAW, in Africa the increased risk to human health due to a lack of appropriate safety precautions is a major concern about synthetic insecticide use (Day et al., 2017). Resistance management is likely to be successful when combined with routine monitoring of pests, use of reasonable treatment thresholds, and the full use of nonpesticidal methods, such as biological and cultural control, field sanitation, and host plant resistance. Judicious and appropriate use of synthetic insecticides is essential for the successful management of FAW and to sustain the increased productivity of maize in Africa. The recent invasion of FAW has alarmed governments of numerous African countries and caused them to deploy a massive pesticide spraying program as an emergency response in FAW affected areas, mainly to maize fields to protect against crop damage and prevent the expansion of the pest. In recent surveys conducted in Kenya and Ethiopia, it has been noted that farmers are applying different types of unregistered synthetic insecticides (Daves et al. 2009), possibly because of the invasive nature of the pest, which requires a rapid response and a lengthy pesticide registration process.

In the present study, three insecticides showed different levels of efficacy against FAW larvae. Development and deployment of an effective integrated pest management strategy, which can provide sustainable solutions to effectively tackle the adverse effects of FAW, is required. Dagar et al. (2020) suggested that use of emamectin benzoate can be an effective tool in Integrated Pest Management program of Helicoverpa armigera. On the basis of the present study, 
similar suggestion can also be given for emamectin benzoate for FAW.

\section{Conclusion}

It is very important to screen the bio-efficacy of insecticides to exploit them in pest management programs; a pest like FAW has significant importance in several crops. In the present investigation it is apparent that all the three test insecticides are toxic to third instar larvae of FAW at different concentrations. Among the test insecticides emamectin beznoate comes first to control the pest at significantly low concentrations like less than $1 \%$ under laboratory conditions. Rest of test insecticides may need quite higher concentrations to kill the test insect larvae. Hence, it can be recommended to use emamectin benzoate for pest managements programs.

\section{Acknowledgement}

The authors show their deep gratitude to Coordinator, Department of Zoology and Department of Agrochemicals and Pest Management for providing necessary laboratory facilities.

\section{References}

Ali A, Luttrell RG and Pitre HN. (1990) Feeding sites and distribution of fall armyworm (Lepidoptera: Noctuidae) larvae on cotton. Environ. Entomol. 19: 1060-1067.

Andrews KL. (1990) Latin American research on Spodoptera frugiperda (Lepidoptera: Noctuidae). Florida Entomol. 71: 630-653.

Capinera JL. (2017) Fall Armyworm, Spodoptera frugiperda (J. E. Smith) (Insecta: Lepidoptera: Noctuidae). http://edis.ifas.ufl.edu/in255.

Dagar VS, Mishra M and Kumar S. (2020) Effect of dietary stress of emamectin benzoate on the fitness cost of American bollworm, Helicoverpa armigera (Hübner, 1808). Int. J. Trop. Insect. Sci. https://doi.org/10.1007/s42690-020-00168-x
Daves CA, Cook DR and Steed T. (2009) Efficacy of selected insecticides against fall armyworms in pastures. Arthropod Management Tests 34: https://doi.org/10.4182/amt.2009.F43

Day R, Abrahams P, Bateman, M, Beale T, Clottey V, Cock M, Colmenarez, Y, Corniani N, Early R, Godwin J, Gomez J, Moreno PG, Murphy ST, Oppong-Mensah B, Phiri N, Pratt C, Silvestri S and Witt A. (2017) Fall armyworm: Impacts and implications for Africa. Outlooks Pest Manage. 28: 196-201. https://doi.org/10.1564/v28_oct_02

Ganiger PC, Yeshwanth HM, Muralimohan K, Vinay N, Kumar ARV and Chandrashekara K. (2018) Occurrence of the new invasive pest fall armyworm Spodoptera frugiperda (J. E. Smith) (Lepidoptera: Noctuidae) in the maize fields of Karnataka India. Curr. Sci. 115: 621-623.

Koffi D, Rosina K, Vincent YE, Komi A, Medetissi A, Georg G and Robert LM. (2020) Natural enemies of the fall armyworm, Spodoptera frugiperda (J.E. Smith) (Lepidoptera: Noctuidae) in Ghana. Florida Entomol. 103: 85-90.

Kondidie DB. (2011) Genetic variability and gene flow of the fall armyworm Spodoptera frugiperda (J.E. Smith) in the western hemisphere and susceptibility to insecticides. Dissertations Student Research Entomology. 7. http://digitalcommons.unl.edu/ entomologydiss/7.

Malo EA, Bahena F, Miranda MA and Valle-Mora J. (2004) Factors affecting the trapping of males of Spodoptera frugiperda (Lepidoptera: Noctuidae) with pheromones in Mexico. Florida Entomol. 87: 288-293.

Mink JS and Luttrell RG. (1989) Mortality of fall armyworm Spodoptera frugiperda (Lepidoptera: Noctuidae) eggs, larvae and adults exposed to several insecticides on cotton. J. Entomol. Sci. 24: 563-571.

Prasanna BM, Huesing JE, Eddy R and Peschke VM. (2018) Fall armyworm in Africa: a guide for integrated pest management, CIMMYT, USAID, México, pp. 109.

Sisay B, Tefera T, Wakgari M, Ayalew G and Mendesil E. (2019) The efficacy of selected synthetic insecticides and botanicals against fall armyworm, Spodoptera frugiperda, in maize. Insects 10: 1-14. 